\title{
東京都の「世界都市」化戦略と政治改革 開発主義国家がネオリベラル化するとき
}

\section{“Global City" Strategies of Tokyo and Political Reform:}

How could a Developmental State be Neoliberalized?

\section{上野淳子}

\section{Junko UENO}

This paper aims to examine the changing nature of the Japanese and Tokyo's political system, which have driven spatial reformation and resulted in socio-spatial polarization in Tokyo after the bubble economy burst.

By analyzing the policy changes, this paper reveals three points. Firstly, the destruction of inter-area redistribution system and the new market-oriented, urban development policy demonstrate the neoliberalizaion of Japanese "developmental state." The government has reduced "inefficient" public investment in rural area and concentrated investment in Tokyo to promote large-scale development project by private firms. Though the Japanese government has still guided development, the political system became different from a "developmental state."

Secondly, spatial reformation of Tokyo has been enabled through neoliberal reformation in other realm by Tokyo Metropolitan Government (TMG). TMG has placed top priority on spatial reformation to become a "Global City" at the expense of welfare, medical services and education.

Finally, fiscal crisis and fear of losing international status have urged the Japanese government and TMG for neoliberal reform. Tokyo's deteriorating competitiveness will continue to provide a further motive for exploring neoliberal strategies.

\section{1. 問題の所在}

東京1)が経験した構造変動をどのように理解すべきか。一都市のグローバル化研究に おいて、東京はその理論の試金石として、国内外の研究者の関心を集めてきた。東京は 「世界都市」と呼べるか、欧米都市とは異なる東京の特殊性をどのように捉えるべきか [Sassen, 1991; Fujita, 1991; 町村，1994; 園部，2001]。本論文では、これらの研究成 果をふまえ、東京の特殊性を「開発主義国家」型都市という視角から捉える。その上で、 バブル崩壊以降に東京が経験した都市リストラクチャリングを、これまで日本経済の発展 を支えてきた開発主義国家体制がネオリベラル化する過程のなかに位置づけて分析する。 バブル崩壊後の1990年代後半から現在までに、東京は社会－空間構造の分極化を経験 
した。分極化を牽引した力の一つは、都心部から臨海部における大規模再開発の進展であ る [上野，2008］。都市再開発の規制緩和をうけ、2000年代初めから東京は大規模再開 発に沸き、「不動産バブルの再来」「東京の一人勝ち」と言われた。ただし、大規模再開発 は東京のなかでも都心から臨海部に集中し、産業空洞化悩む大田区、墨田区の中小企業 や、震災対策の遅れを心配する木造密集地域の住民は恩恵を被っていない［矢作，2002］。 2000 年代の大規模再開発は、東京に拧ける既存の地域格差を一層強化した。

東京の社会一空間的分極化を進めたもう一つの力は、日本社会全体における格差拡大 である。日本社会の格差拡大や階層固定化の傾向に関しては、近年になって格差が拡大 したわけではない［盛山，2000；石田，2008］、格差拡大の主な原因は高齢化である [大 竹，2005］などの指摘があるものの、若年層における賃金格差の拡大は事実である [太田， 2006]。東京に扔いても、この 10年で雇用の非正規化、所得の二極分化、若年失業の増加、 貧困層の拡大と中間層の生活不安定化が進んだ [進藤，2009］。こうした社会経済的な格 差拡大は地域格差の拡大として表れている [橋本，2007］。社会のなかの格差拡大と地域 的に偏った大規模再開発の進行があいまって、東京の社会一空間構造の分極化が進んだと 言える。

では、東京の社会一空間的分極化は、どのような政治体制の産物であるか。1990年代 までの「世界都市」研究では、東京は分極化のレベルが低く、製造業に大きく依存し国家 の強い統制下にあるという点で、欧米とは異なる「開発主義国家」型世界都市であるとさ れてきた [Fujita, 2003]。しかし、1990年代以降に進行した日本企業の本格的なグロー バル化とそれにともなう国や自治体の新自由主義的改革は、開発主義国家」型世界都市 という図式の見直しを迫っている。

本論文の構成は次のとおりである。まず、グローバル経済下における都市再編の分析枠 組みとして「世界都市」論をとりあげ、欧米の世界都市とは異なる東京の特徴と、「ネオ リベラル化」概念が出てきた背景を整理する。その上で、バブル崩壊以降の日本の変化を 概観し、開発主義国家」型都市の「ネオリベラル化」を分析するための留意点を示す（2 章)。次に、バブル崩壊以降の東京都捛よび東京 23 区の政策の動向から、東京の「ネオリ ベラル化」を検討する (3 章)。全体的な制度の動向は市場への接近、すなわち「ネオリ ベラル化」の浸透を表す。最後に、「ネオリベラル化」概念の有効性と今後の課題を指摘 したい。

\section{2。「世界都市」論から「ネオリベラル化する都市」論へ}

\section{2-1 東京は「世界都市」か}

1990年代までの日本都市、特に東京の構造再編に関する研究では、J. Friedmann やS. Sassenらの「世界都市」仮説［Friedmann, 1986; Sassen, 1991］を適用する試みが盛ん 
になされた。S. Sassenらの「世界都市」仮説によれば、都市がグローバル・ネットワー クに包摂される過程で、世界都市には(1)多国籍企業の中枢管理機能が集積し、(2)国際的な 金融センターが形成される一方で、(3)製造業が海外に流出し、(4)産業構造の転換が職業構 成と所得階層の急速な分極化をもたらす。しかし、東京における「世界都市」仮説の検証 によって、ニューヨークやロンドンとは異なる東京の特殊性が明らかになる。

まず、東京では分極化の〈兆し〉が見られるものの、ニューヨークやロンドンに比べれ ば分極化の程度は非常に低かった［町村，1994，1998; 園部, 2001]。また、国際的な金 融活動が活発なニューヨーク、ロンドンに対して、東京の経済活動はあくまで製造業を基 盤としている。脱工業化は進んでいるが、東京はいまだに製造業の技術開発に重点を置い た「新工業都市」であった [Fujita, 2003]。東京にある多国籍企業は国内の大企業であり、 東京は日本企業が海外進出する足がかりの役割を果たしていた [Hill and Fujita, 1995]。 結局、ニューヨーク、ロンドンが世界中から資本の流れ込むマネー・アブソーバー型世界 都市であるのに対して、東京は国内企業が生み出した富を送り出すマネー・サプライヤー 型世界都市だと言えよう［加茂，2005］。

東京は世界経済に強く包摂されながらも、分極化の程度と産業基盤はニューヨークやロ ンドンと全く異なり、その違いは都市構造の背後にある政治経済体制によって説明され た。自由主義的な伝統をもち、市場における競争が経済を牽引する英米に対して、日本は 開発主義と捉えられる [Fujita，2003］。日本の開発主義は、産業化に適した金融システ ムを編成して、持続的な経済成長のために戦略産業へ重点的に資源を注ぎ込む体制をつく りあげると同時に、労㗢者の協力をとりつけるため短期的利益の追求を排した [Hill and Kim, 2000: 2174-2176]。競争ではなく協調、個々の利益ではなく国益の追求、市場では なく国家が日本の政治経済体制を特徴づけており、国家の成長戦略の下で発展してきた東 京は、「開発主義国家」型の世界都市と呼ぶことができる。

2-2「開発主義国家」型世界都市モデルの限界と「ネオリベラル化する都市」論

米英の都市の観察から生まれた「世界都市」論が、東京を含めたアジアやラテンアメリ カなどの都市へ適用されるにつれ、その限界が明らかになる。R. Hillらの議論は、世界 都市仮説の変動図式がもつ一般・収斂モデルに、国家諸機構や社会制度といった制度要因 を加味することで都市の多様なありょうを明らかにし、歴史的経路依存や発展の多系性 を説明するモデルに組み替えることに成功した、いわば世界都市論の新制度論的転回を もたらしたと言えよう [丸山, 2010］。その後の議論は、(1)経済中心の分析から政治・制 度分析へ、(2)一般・収斂モデルから経路依存・多系化モデルへと展開していく。その中 心にあるのが、2000年代以降、欧米都市を対象に展開された「ネオリベラル化する都市 (neoliberalizing cities)」論である。

Hill らの議論は、日本の政治経済体制（開発主義国家）によって世界都市東京の特殊性 
を説明することに成功した点で評価できるが、以下 2 点で限界を抱える。第一に、時代的 な制約である。彼らが検証した時代は1990年代半ばまでであるが、その後の日本は大き な変動にのみこまれる。K. Fujitaは、戦後日本の成長を支えた政治経済体制として、国 の産業政策と社会資本への投資と並んで企業社会をあげ、1990年代半ばに国内政治の危 機に由来する調整危機は前者2つの刷新をもたらしたが、「最も重要なことに、調整制度 としての企業社会はほとんど変わっていない」[Fujita，2003: 254] と主張する。しかし、 雇用の安定と福祉の提供を担ってきた企業社会は1990年代後半から大きく摇らぐ。第二 に、ネオリベラリズムを狭く捉え2)、その影響を過小評価している。彼らは、「新自由主義 的な政策の導入だけで都市や国家が新自由主義レジームに移行するわけではない」のであ り、汨本の国家は、公営企業の民営化や規制緩和、地方分権といった新自由主義的な要 素を怨意的に採用しており、新自由主義への転換というょり、ポスト開発主義への移行で ある」という [Fujita and Hill, 2008: 4]。単なる政策導入とレジーム・シフトは区別す べきだが、新自由主義的な要素は開発主義国家の中核に組み込まれており、その影響を軽 視すべきでない。

「ネオリベラル化する都市」論は、こうしたHillらの限界を乗り越える可能性をもつ。 この議論は、経路依存性、創造的破壊、都市の重要性という 3 点で、旧来のネオリベラリ ズムに関する議論と異なる。第一に、ネオリベラリズムを思想・イデオロギーとしてで はなく「地政的・地理経済的なプロジェクト」として把握し [Brenner and Theodore, 2002: 349]、イデオロギーとしてのネオリベラリズムが「複数の制度形態や政治的行為 の中で生産・再生産されるプロセス」を「ネオリベラル化」として捉えようとする [Peck and Tickell, 2002: 383]。地域の政治的・経済的条件に応じて様々なネオリベラリズムが 生じ得る。

第二に、ネオリベラル化の過程は、現存する制度の破壊と、市場志向の経済成長・商品 化・資本のルールに適したインフラの創造という2つの過程として捉えられる [Brenner and Theodore, 2002: 362]。ネオリベラリズムの議論では、公共住宅の廃止や労働規制 の緩和のように、既存の制度の破壞や政府が市場から撤退する局面のみが注目され、批判 されてきた。しかし、市場志向の新たな制度・インフラの創造を通じて政府の統制が強化 される局面も含めて検証することで、複雑かつ矛盾にみちた制度変化の過程を捉えること ができる。

第三に、ネオリベラル化の過程に抢ける都市の重要性である。ネオリベラル化がとも なう諸制度の創造的破壊は、「あらゆる空間的スケールで進行するが、都市に抢いて最も 激しく生ずる」[Brenner and Theodore, 2002: 367]。国境を越えた資本の流動化はナシ ヨナルなスケールの重要性を減じ、福祉国家の後退によって行為主体としての地方政府 の重要性は増している。N. Brennerらはネオリベラリズムが地域に定位される諸相とし て、12のテーマ群をあげる [Brenner and Theodore, 2002: 369-372 Table 2]。これら 
は、5つの領域の再編過程に分けられる。1 1国家・自治体の再編（「政府間関係の再定義」 「財政改革」福祉国家の再編」地方自治体の制度的インフラの再配置」)、(2)市場領域の再 編（「自治体の公的セクターと集合的インフラの民営化」「都市住宅市場の再編」「労働市場 規制の再設計」)、(3)空間の再編、新たな地理的不均等発展（「領域開発戦略の再編」建造 地域と都市形態の変容」「地域間の政策移転」）、(4)市民社会の再編（「都市の市民社会の再 調整」）、(5)言説空間の再編（「都市の表象のやり直し」）丸山，2010］。上記は過去20年 の欧米都市における経験から導き出されたものであり、ケインズ主義的福祉国家の存在を 前提とする。日本都市のネオリベラル化を分析するためには、開発主義国家を出発点とす る必要がある。次節では、バブル崩壊後の日本の変容過程を追いながら、開発主義国家の 解体にみられる特徵を指摘し、東京がネオリベラル化する過程を分析するための留意点を 提示する。

\section{2-3 開発主義国家の解体、あるいはネオリベラル化}

現代日本における開発主義国家体制は、企業社会と、国家による産業政策および公共事 業から成る。日本では、強い経済規制と公共事業によって完全雇用と所得再分配を達成す るメカニズムが形成され、欧州的な福祉国家の機能を代替する補償メカニズムの役割を担 った [武川，2007］。ケインズ主義的福祉国家では国家が社会階層の上から下へ再分配を 行うが、開発主義国家では企業が労働者の生活安定を保障し、公共投資を通じて地域間・ 産業間の再分配がなされてきたと言える。

日本企業のグローバル化は、開発主義国家の福祉代替機能に改革を迫った。米国との経 済摩擦や円高におされて企業の海外進出は1980年代半ばから開始したが、製造業の本格 的な海外進出は 1990 年代前半に進み、アジア地域へ集中的に現地法人を展開した。しか し、日本企業の競争力は、低賃金・長時間労働を可能にする企業支配と、低額な資材等を 拠出する下請け構造、税制優遇など開発主義国家の産業支援策に支えられており、アジア 進出は日本企業の競争力をかえって低下させてしまう［渡辺，2004］。バブル崩壊後の不 況のなか、日本企業は競争力回復を求めて、企業社会の改革と「構造改革」の要請へと向 かった。

企業社会の改革は、労㗢力の圧縮・非正規雇用化と企業内福利の切詰の 2 方向から進め られた。労働力の非正規雇用化は、1999年の労働者派遣法の改正で大きく進展し、2007 年時点で雇用者全体に占める非正規雇用者の割合は $1 / 3$ を超えた。また、企業内福利の切 詰 ${ }^{3)}$ にって労働力を再生産する力が弱められた。日本の社会保障制度は他の先進国に比 べて未整備で、特に雇用（失業関連）、住宅、家族（育児、家族介護関連）の分野につい ては脆弱である4)。その分を企業内福利が補ってきたが、企業改革はそれすら奪いつつあ る。

競争力回復をめざす企業の矛先は自由な企業活動を妨げる制度へと向かい、自民党と官 


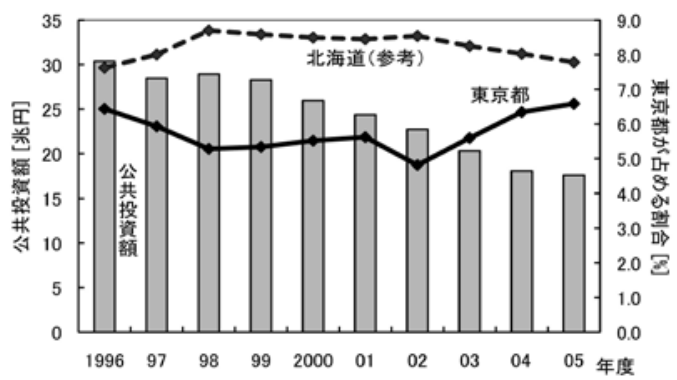

注 : ここでは、国民経済計算における一般政府による固定資本形成への支出額を「公共投資額」としている。一般政 府は、日本政府、都道府県、特殊法人などを含む。また、土地代等を含まない。

資料：内閣府, 2008, 『県民経済計算年報』から著者作成。

図 1 全国の公共投資額および東京都への投資が全国に占める割合

僚機構に対する「構造改革」の圧力を生みだした。開発主義国家は産業振興政策や都市基 盤などの整備によって企業社会を支えるとともに、企業福祉からこぼれ落ちる周辺層・地 域には公共投資という形で再分配を行ってきた。小泉「構造改革」は、分配」型システ ムを「効率」型システムに移行させる改革であった［上村・田中，2006］。2001 年6月 に閣議決定された「今後の経済財政運営及び経済社会の構造改革に関する基本方針」(い わゆる「骨太の方針」）では、経済再生のための不良債権処理と規制改革の重要性を示し た上で、現状にあわない「非効率な部分」として「社会資本整備」「社会保障」「国と地 方の関係」をあげて構造改革の必要性を述べる。この方針に則り、効率性の低い公共事業 の見直しや、国から地方への国庫補助負担金・地方交付税の削減5が行われ、再分配機能 は縮小された。

全国的には国からの再分配は縮小したが、同時に大都市への集中投資が進む。公共投資 の総額は 1990年代後半から一貫して減少している。地域別にみると各地域が公共投資の 総額に占める比率はほぼ横ばいであるが、東京都はバブルの崩壊とともに減り続けたのち、 2002 年度を底に増加へ転じた（図 1)。2002年施行の「都市再生特別措置法」は、大都 市都心部に「都市再生緊急整備地域」を設定し、その地域に民間企業の再開発を促進する ような規制緩和、税控除、公共投資を集中させており、公共投資比率の変化にもその影響 が表れている。東京都を除く関東地域も2005年度には増加するが、東京都に打ける反転 の早さからは、都市再生」の眼目が「東京再生」、特に「東京都心部の再生」であったこ とがうかがわれる。公共投資額と比率の変化は、国の方針が「国土の均等発展」から東京 への「選択的集中」へ移行したことを示す。

長期不況とグローバル化の進展は、1990年代後半に入って企業および政府に対する〈改 革〉圧力を高めた。その結果は、企業社会の弱体化と国から地方への再分配機能の縮小で

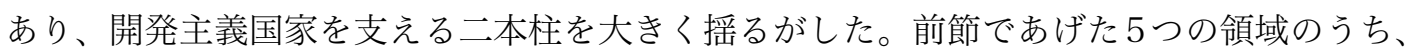
(2)市場領域の再編が日本では企業社会の改革に相当し、それが(1)国家・自治体抢よび(3)空 
間の再編へとつながった。都市再生」政策だけに注目すれば、依然として国家が開発を主 導する開発主義国家体制が維持されているように思われる。しかし、東京における市場志 向の空間再編は、他の地域・領域の「効率化」の上に成立している（付表 1 参照）。ネオ リベラル化の分析に際しては、一つの領域の再編だけでなく、異なる地域や領域との連関 を注視する必要がある。この点をふまえ、東京都と東京23区のネオリベラル化を検証す る。

\section{3．東京の新自由主義的再編}

3-1「世界都市」への挑戦とネオリベラル化：東京都の重点事業の変化

(1)「世界都市」からの転落

国のネオリベラル的改革と歩調をあわせるように、東京都では「世界都市」化にむけ た改革が進行した。改革の推進力のひとつは巨額の負債残高である。公債残高は1990年 度に国で約 166.3 兆円（税収の約 2.8 倍）、都で約 2.3 兆円（同、約 0.5 倍）であったが、 2000 年度に国で約 367.6 兆円（同、約 7.3 倍）、都で約 7.7 兆円（同、約 1.8 倍）へと大き く増えた。財政再建の手段として、国は地方への配分や社会福祉制度の見直し、“無䭾な” 公共事業の削減を行って周辺地域・周辺層への配分を減らしてきた。東京都は、社会福祉 制度を見直して民営化や委託を進めたが、「世界都市」化をめざしてインフラ整備や再開 発を促進している点で日本の他の地域とは異なる状況にあるだろう

東京都を改革に駆り立てるもうひとつの力は、現状への強い危機感である。2000年末 発表の『東京構想2000』では、日本の現状を「長引く経済の低迷、深刻な雇用危機、心 の荒廃などさまざまな問題が山積しており、まさに危機的な状況」と捉光、「首都東京には、 わが国の危機の本質が縮図のように顕著に表れており、経済活動の低迷や都市としての魅 力の襄失は、東京の国際競争力を低下させ、わが国全体に深刻な影響を及ぼしている」た め、東京を再生することが「日本を再生していくことにもつながる」と訴える[東京都， 2000: 5]。東京構想2000』が予測する東京の未来は決して明るくない。2015年の東京は 人口減少と高齢者の急増に直面し、労働力人口減少下で「経済成長を持続することは一段 と難しくなっていく」と予測する [東京都, 2000: 11-17]。目標として「東京の魅力を高め、 世界に冠たる国際都市東京となる」ことを揭げつつも、現状は「外国為替市場に拀いて二 ューヨークとの格差が拡大するなど、国際ビジネスセンターとしての地位が危ぶまれて」 いて、さらに、シンガポールなど「アジアの諸都市の国際競争力が高まってくる」なかで 「アジアの中でも東京の相対的地位が低下しつつある」と分析する [東京都，2000: 230］。 東京の国際的地位の低下は、将来起こり得ることではなく、既に現実のものとして認識さ れている。

東京の現状への危機意識、国際競争のなかで転落しつつあることへの恐怖が、東京都を 
都庁内の改革へと追い立てる。同時に、東京都の目は国へも向けられる。都は、「首都東 京に対する国費の集中的な投入が不可欠である」として、東京への重点的な公共投資を求 めるとともに、「民間の資金やノウハウの活用など事業手法の工夫を行い、活発な民間の 投資の動きを、望ましい都市づくりに結び付けていくことが重要である」と主張する［東 京都，2000: 24]。都市（東京）の再生が日本の再生」「国際競争の激化」「民間の資金や） ウハウの活用」という文言は国の「都市再生基本方針」(2002年7月）に反映され、東京 への集中投資を正当化する役割を果たした。

(2)福祉の削減と「世界都市」開発への傾注

では、東京都の改革と「世界都市」化はどのように進んだか。バブル崩壊後に登場した 青島幸男都政（任期 1995 年 4月～1999年 4月）は、市民派的な装いとは裏腹に、財政面 では鈴木都政の「世界都市」化を継承し、福祉や環境、防災など「世界都市東京」化に非 適合的な政策分野においては、財政再建という観点から民間委託や市民との協働が進め られた [進藤，1998: 8-21］。1999年に始まった石原慎太郎都政（1999年4月から現在3 期目）もこれまでの「世界都市」化戦略の延長上にある。

ただし、石原都政の「世界都市」化戦略は、それまでと 3 点で大きく異なる。第一に、 対象範囲が東京都のみでなく、東京圈全体に広がった。東京構想2000』で国による「都 市再生」の下地をつくり、環状メガロポリス構造」という東京圈全体の空間再編を提案 している点で、国や周辺県をまきこんだ「世界都市」化戦略を企てていると言えよう。第 二に、鈴木都政がめざした多核心型都市開発の否定である。環状メガロポリス構造」では、 首都高速中央環状線に囲まれた都心・副都心の区を「センター・コア・エリア」と名付け、 都心・副都心を一体的に捉える。第三に、国際金融情報機能に特化せず、幅広い機能をも つ「世界都市」を想定する。センター・コア・エリア」の将来像は「国際ビジネスセンタ 一機能をはじめ業務、商業、文化、居住等多様な機能が高密度に集積し、「歴史的・文化 的遺産がまちづくりに活かされ、首都の風格を備えた都市空間」と描かれている[東京都， 2000: 48-49]。このため、民間投資を呼び込んでオフィスや住居を整備するだけではなく、 歴史的・文化的まちづくりや水辺空間の整備、海外とのアクセス改善など、大がかりな空 間再編が必要な施策にあげられている。世界都市」に向け、これほどの空間再編を厳しい 財政下でどのように調整し進めているかを、都の重点事業を対象として検討しょう。

石原都政は 2002 年 7 月に「重要施策についての基本方針」を策定し、7つの戦略的取組 を次年度の「重点事業」に揭げて都政の独自性を打ち出した。これ以降、毎年重点事業を 指定している。年度ごとに戦略の位置づけや各戦略の下に置かれる事業が少しずつ異なり、 大きく 3 期に分けられる。(1) $2003 \sim 05$ 年度の都の構造改革に向けた 3 カ年プロジェクト、 (2) 2006、2007年度のオリンピック誘致の準備期、(3)2008～10年度のオリンピック開催 のための都市改造期。3つの時期ごとに、戦略の位置づけの変化を確認しょう（図2）。 

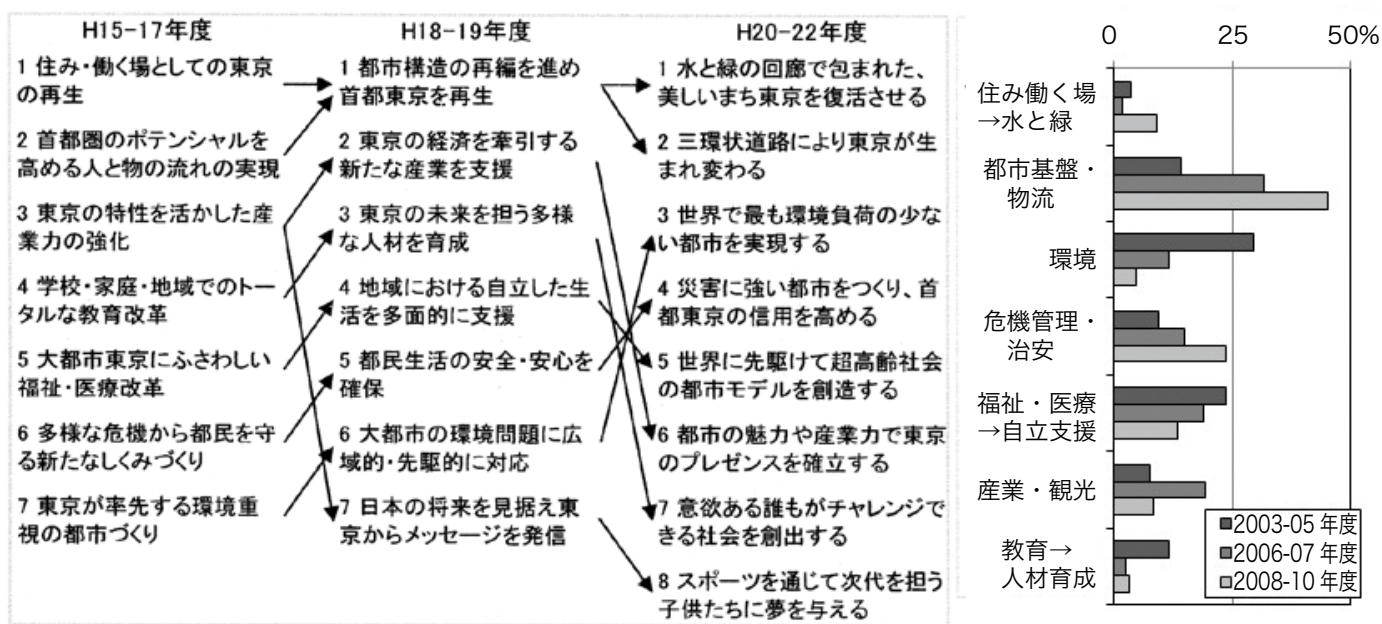

図 2 および図 3 の資料 : 東京都『重要施策及び平成 15 年度重点事業〜 構造改革を推進するための戦略指針 〜、平 成 16 年度から平成 19 年度の各年度版『重点事業』、『「10 年後の東京」への実行プログラム 2008』

図 3 の注 : 1.2006 年度以降については、複数分野にまたがる施策はそれぞれの分野に再揭されているため、分野ことと の事業費比率の合計は 100\%を超える。

2. 事業費総額は 2003-05 年度 666 億円、2006-07 年度 1,627 億円、2008-10 年度 1 兆 6,700 億円である。

図2 重点的に取り組む分野の位置づけの変化（左）

図 3 戦略分野ごとの事業費の比率の推移(右) (分野の番号は掲載順)

(1)2003～05年度から (2)オリンピック誘致の準備期への変化は、4つである。まず、重 点事業から住宅分野の事業が消えて、「1. 住み働く場」と「2. 物流」が「1. 都市構造再編」 へまとめられている。また、2006年度には重点事業として「東京オリンピック招致に向 けた都民運動」が初めて揭げられた（分野7の一部）。さらに、教育分野の目標は青少年 の教育から、障害者の就労支援や地域社会を担う人材育成などの「人材育成」へと変わり、 福祉・医療関連の戦略は「大都市東京にふさわしい福祉・医療改革」から「地域における 自立した生活を多面的に支援」へと自立支援の強調が目立つようになる。(2)オリンピック 誘致の準備期から (3)オリンピック開催のための都市改造期への変化は、「1. 都市構造再編」 が「1. 水と緑の回廊」と「2. 三環状道路」の整備にわかれ、オリンピック関連の事業が 独立した分野 (分野8) として分離したことである。2003年以降、一貫して都市構造再 編に関する分野が重点分野の第一に掲げられ、丸の内地区や品川駅・渋谷駅の整備など都 心部の民間プロジェクトによるまちづくりが具体的プロジェクトとして示されていた。

次に、時系列で比較するため各事業を分類し直し、7つの戦略分野に配分される事業 費の比率の推移を示した（図 3)。各戦略分野の事業費比率から、石原都政の目指したも のが浮かび上がる。2003〜05年度に重点的に取り組まれ、近年比率が減少した分野は、 環境、福祉、教育の 3 分野である。就任当初の石原都知事はディーゼル車反対を打ち出し ており、初期の環境分野の比率の高さに反映している（2003年度のディーゼル車対策事 業費約 85 億円、重点事業費の約 $32 \%$ )。また、教育分野では都立高校改革（学区撤廃、進 学指導重点校や中高一貫校の設置、自立経営の促進、統廃合など）を進め、福祉・医療分 
野では障害者の通所施設など地域生活支援の基盤を整備した上で、施設の民間委託を行つ た。

増加した分野は、都市基盤・物流、危機管理・治安、住み働く場／水と緑の 3 分野であ り、インフラ整備と要約できる。石原都知事の治安対策では外国人犯罪取締りや監視カメ ラ設置などが有名だが、近年の危機管理の施策は幹線道路の整備をともなった沿道の不燃 化、建物の耐震化や浸水対策などインフラ整備に移行している。また、住み働く場／水と 緑の分野では、初期にあった住宅関連の施策が抜けおち、緑化やヒートアイランド対策、 水辺整備などの「水とみどり」のまちづくりへと変わった。7分野のなかで最も変化が大 きいのは、都市基盤・物流分野である。重点事業に途中から三環状道路関連の事業が含ま れたことが同分野の事業費比率の増大および重点事業費総額の伸びにつながっている6)。

産業・観光分野では、中小企業のモノづくり支援（2004年東京しごとセンター開設、 2005 年ナノテクノロジーセンター開設と新銀行東京の開業）を行っているが、重点事業 費比率は小さい。2006-2007年度の比率の高さは、観光客誘致を目的とした水辺整備に よる。

以上から、教育や福祉などの分野で移管・民営化・効率化を進めて財政支出を切り詰め た上で、世界都市」化に向けたインフラ整備に残りの資源を傾注する様子がみえてくる。 変化を空間的にみた場合、東京都全域に関係する医療・福祉・教育関係の支出は削減され ており、東京圈を貫く三環状道路の整備に最も資金をかけ、また、戦略の順位としては都 心部の民間開発を誘導する都市構造再編が一貫して第一に揭げられていた。“非効率な”分 野・地域への支出の削減分をインフラ整備に回し、都心部への市場の投資を喚起して「世 界都市」化を目ざすという戦略は、東京都のネオリベラル化をよく表わしている。

付表 1 も同様の傾向を示す。東京都は『危機突破・戦略プラン』や『東京構想2000』 により東京への重点投資の必要性を訴えて、「都市再生」のための制度を国に整えさせる 一方で (空間の再編)、医療・福祉・教育分野ではコスト削減や民営化、区への移管など の方針を矢継ぎ早に打ち出している（市場領域の再編拉よび国家・自治体の再編）。同時 に、東京女性財団の廃止など管理団体の統廃合をすすめ、市民活動団体を「社会貢献活動 団体」と呼びかえて協㗢の指針を示すなど、市民社会の再編にも手を付けた。他方で、産 業や雇用の施策は目立たない。東京都にとって、「世界都市」化戦略自体が国際金融・観 光などの産業振興・雇用政策につながり、従来からの製造業や中小企業の支援は関心の外 にある。

3-2 浸透するネオリベラル化 : 東京23区の都市開発方針

ネオリベラル化はあらゆるスケールで展開する。東京 23 区に括いても、教育 [谷口， 2008］、住宅［高木，2008］、協㗢」[渡戸，2009］の分野でネオリベラル的再編が進み、 区の政策に影響を与えている。また、千代田区、文京区、足立区では積極的に「NPM行 
表 1 地区計画および用途地域等の見直しにともなう変更

\begin{tabular}{|c|c|c|c|c|c|c|c|c|}
\hline & \multirow{2}{*}{\multicolumn{2}{|c|}{\begin{tabular}{|c|} 
地区計画 (2008 \\
年度末) \\
市街化区域に占め \\
る適用面積の比率 \\
\end{tabular}}} & \multicolumn{4}{|c|}{$\begin{array}{c}\text { 用途地域等の見直しにともなう変更 } \\
\text { (2004 年) }\end{array}$} \\
\hline & & & & & \multirow{3}{*}{$\begin{array}{l}\text { 市街化区 } \\
\text { 域に占め } \\
\text { る変更面 } \\
\text { 積の比率 }\end{array}$} & \multicolumn{3}{|c|}{ 主な変更点 } \\
\hline & & & \multirow[b]{2}{*}{$\begin{array}{l}\text { 規制強化 } \\
\text { 型 }\end{array}$} & \multirow[b]{2}{*}{$\begin{array}{l}\text { 規制緩和 } \\
\text { 型 }\end{array}$} & & \multicolumn{2}{|c|}{ 規制強化 } & \multirow{2}{*}{\begin{tabular}{|l} 
規制緩和 \\
容積率・ \\
建ぺい率 \\
の緩和
\end{tabular}} \\
\hline & & & & & & $\begin{array}{l}\text { 敷地規模 } \\
\text { の最低限 } \\
\text { 度 }\end{array}$ & 高さ制限 & \\
\hline \multirow{5}{*}{$\begin{array}{l}\text { 規 } \\
\text { 制 } \\
\text { 緩 } \\
\text { 和 }\end{array}$} & \multirow{3}{*}{\begin{tabular}{|r|} 
和規 \\
制 \\
緩
\end{tabular}} & 中央区 & - & $73.8 \%$ & $7.9 \%$ & & & 0 \\
\hline & & 足立区 & $3.5 \%$ & $19.2 \%$ & $9.4 \%$ & & & 0 \\
\hline & & 港区 & $1.5 \%$ & $0.3 \%$ & $4.4 \%$ & & & 0 \\
\hline & 強管 & 千代田区 & $13.5 \%$ & $21.8 \%$ & $6.9 \%$ & & & 0 \\
\hline & 化理 & \begin{tabular}{|l} 
墨田区 \\
\end{tabular} & $4.8 \%$ & $5.1 \%$ & $29.0 \%$ & & O & O \\
\hline & \multirow{8}{*}{$\begin{array}{l}\text { 韭 } \\
\text { 関 } \\
\text { 与 }\end{array}$} & 台東区 & $0.9 \%$ & - & - & & & \\
\hline & & 文京区 & 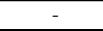 & $0.7 \%$ & $0.3 \%$ & & 0 & \\
\hline & & 北区 & $0.9 \%$ & - & $1.0 \%$ & & & \\
\hline & & 葛飾区 & $2.2 \%$ & $0.2 \%$ & $0.4 \%$ & & O & \\
\hline & & 大田区 & $3.1 \%$ & $0.0 \%$ & $0.1 \%$ & & & \\
\hline & & 品川区 & $1.2 \%$ & $1.2 \%$ & $1.0 \%$ & & & 0 \\
\hline & & 荒川区 & $0.2 \%$ & - & $3.4 \%$ & & & 0 \\
\hline & & 練馬区 & $2.7 \%$ & $0.4 \%$ & $0.9 \%$ & & 0 & \\
\hline \multirow{10}{*}{$\begin{array}{l}\text { 嫢 } \\
\text { 制 } \\
\text { 強 } \\
\text { 化 }\end{array}$} & \multirow{10}{*}{$\begin{array}{l}\text { 規 } \\
\text { 制 } \\
\text { 強 } \\
\text { 化 }\end{array}$} & 新宿区 & $4.9 \%$ & - & $0.2 \%$ & & & 0 \\
\hline & & 板橋区 & $5.9 \%$ & - & $0.4 \%$ & & & O \\
\hline & & 豊島区 & $5.4 \%$ & $1.3 \%$ & $0.0 \%$ & & & \\
\hline & & 江東区 & $5.4 \%$ & $1.4 \%$ & $0.3 \%$ & & & \\
\hline & & 渋谷区 & $7.8 \%$ & $0.9 \%$ & $0.0 \%$ & & & \\
\hline & & \begin{tabular}{|l|} 
目黒区 \\
\end{tabular} & $2.5 \%$ & - & $40.7 \%$ & O & O & \\
\hline & & 世田谷区 & $17.9 \%$ & $2.0 \%$ & $52.4 \%$ & O & 0 & \\
\hline & & 中野区 & $6.2 \%$ & - & $79.0 \%$ & 0 & & \\
\hline & & \begin{tabular}{|l} 
杉並区 \\
\end{tabular} & $3.7 \%$ & - & $84.7 \%$ & 0 & & \\
\hline & & 江戸川区 & $7.7 \%$ & $3.8 \%$ & $80.8 \%$ & 0 & 0 & \\
\hline
\end{tabular}

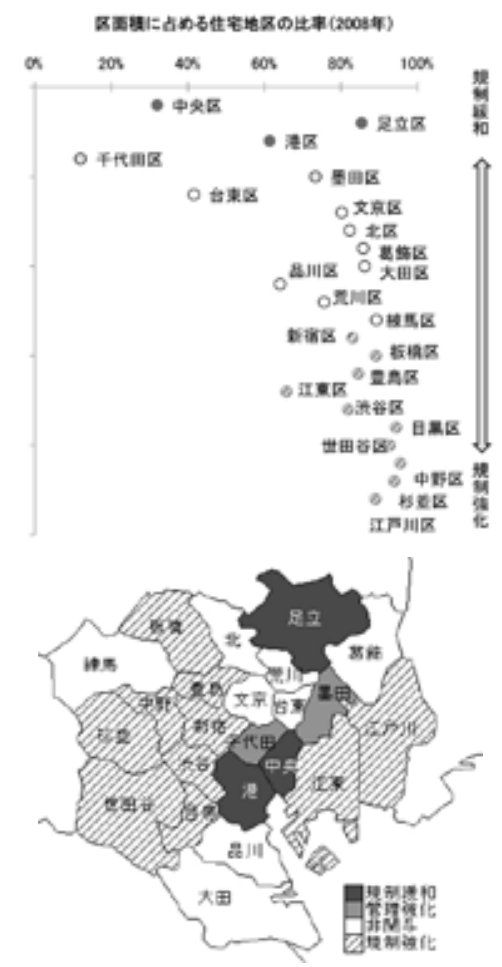

図 4 都市開発の規制と区の面積に 占める住宅地区の比率

表 1 および図 4 の資料 : 東京都都市整備局『建築統計年報 2008 年版』、財団法人東京都防災・建築まちづく りセンター「用途地域等の見直しの概要」『町並み』35 号から作成。

政改革」が実行されている [久保木，2004］。東京都のネオリベラル化は区の施策にどの ように影響するか。東京都は「世界都市」化に向けたインフラを整備し、都心部では民間 開発を規制緩和によって促進しており、都市開発は都のネオリベラル的政策のなかで重要 な位置を占めていた。そこで、都市開発に限定して、東京23区の方針が民間開発を促進 するものかどうかを検討する。特別区制度のもとで区の権限はかなり限定されており、本 節では地区計画の適用状況と2004年に行われた用途地域等の見直し状況から、各区の都 市開発方針を探る。

地区計画制度は 1980 年に創設され、街区単位で建物の用途・高さ・デザインや公園の 配置等を住民参加 7)で調整し条例化できる。基本的には規制強化型であるが、1990年以降、 規制緩和型の地区計画が導入された。また、2004年の用途地域等見直し 8) は2002年の 都市計画法等の改正で高い容積率や絶対高さ制限など新たなメニューが登場したことによ る。

まず、地区計画の適用状況であるが、ほとんどの区は規制強化型の地区計画が多く、特 に世田谷区は 1990 年代から地区計画の導入を進め導入比率は 2 割近い（表 1 ）。中央区、 
足立区、千代田区、墨田区は規制緩和型の地区計画の導入率が高く、なかでも中央区の比 率は23区の中で突出している。中央区は、日本橋人形町などで広範囲に規制緩和型の地 区計画を指定しており、マンションの増加と人口回復につながった。しかし、マンション の建築紛争も頻発し、2004年以降に規制緩和の幅を切り下げたり、緩和を廃止している。 足立区は千住周辺に規制緩和型の地区計画を指定し、大規模開発の促進をはかっている。

次に、用途地域等の見直し状況を確認する。見直しを行った面積は、東京都全体で約

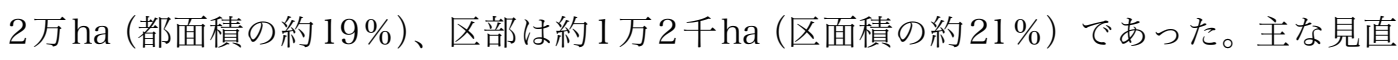
しは(1)高い容積率・建ぺい率の指定、(2)敷地面積の最低規模の指定、(3)高さ制限の3つで、 (1)が規制の緩和、(2)(3)強化である。(1)高い容積率・建ぺい率を指定した区は千代田区、 中央区、荒川区と板橋区で、後の 2 区は幹線道路沿いで老朽木造住宅の建替元促進や防災 のため、建べい率を $60 \%$ から $80 \%$ に変更した。(2)敷地面積の最低規模の指定は、目黒区、 世田谷区、中野区、杉並区、江戸川区の5区で行われた。区域の 4 割〜 8割を指定し、敷 地細分化とミニ開発の抑制をはかっている。(3)高さ制限は文京区、墨田区、目黒区、世田 谷区、練馬区、葛飾区、江戸川区の 7 区で行われ、良好な景観形成のために建物に対する 高さ制限を強化する地域が指定された。また、上記 3 点の変更とは別に、足立区では道路 等の整備と合わせて市街地の形成を進めるため、区域の約 1 割に対して容積率を緩和した。

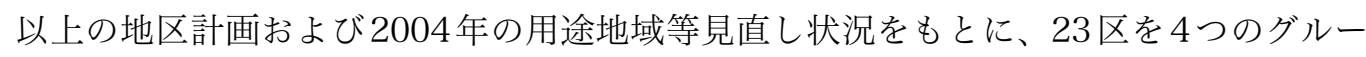
プに分けられる（表 1)。(1)規制緩和を進めた 3 区、(2)規制の緩和と強化を地域によって 使い分けて空間を管理する2区、(3)現行の開発規制を変更しない非関与型の 8区、(4)規制 強化型の 10 区である。区に占める住宅地区の比率が低いほど、都市開発規制を緩和する 傾向がみられる（図4)。住宅地区比率の低さは都心への近さと関連するため、都心の区 ほど住民ではなく市場からの圧力をうけて開発規制を緩和する傾向にあると言える。例 えば、『代田区第3次基本構想』（2002年）では、「千代田区を構成するのは、住み、㗢き、 学び、集う 100 万人の人びとと企業です。」と述べて抢り、千代田区の視線は住民だけで なく企業や観光客にも向けられている。また、人口回復を狙う中央区や、「区外の人たち からも「生活してみたい・訪れてみたい」と支持される“あだちづくり”」(2006年『足立 区都市計画マスタープラン』）と謳い大規模開発に期待する足立区では、外から新たな住 民をひきよせるために開発規制を緩和していた。東京都と国が「都市再生」の名のもとで 都心・副都心の開発を促進していることも区の開発方針に影響しているだろう。また、都 心でなくても、足立区のように公営住宅の多さによる民生費比率の高さが財政を圧迫して いる区では、市場重視の都市開発を志向している。

\section{結論}

本論文では、「ネオリベラル化」という視角から、バブル崩壊後の東京の社会一空間的 
分極化、特に空間再編を推し進めた政治体制を検討した。2000年代に東京が経験した大 規模再開発のラッシュは、他の地域を犠牲にして東京へ資源を傾注し、規制緩和により民 間投資を喚起する「都市再生」の仕組みに支えられていた。政府が開発を主導し、全体の 経済成長を図る体制は、旧来型の開発主義国家体制であるように思われる。しかし、開発 主義国家に特徵的な産業間・地域間の再分配機能が破壊されている点で、旧来の開発主義 国家体制とは一線を画する。むしろ、「効率性」の名のもとに衰退する地域の公共事業を 削減し、東京への集中投資と規制緩和によって民間開発を後押しする様からは、開発主義 国家の中核に扔いてネオリベラル化が進行していると言える。ネオリベラル化の傾向は国 だけでなく東京都の施策にも表れている。重点事業の分析によれば、戦略の順位としては 都心部の民間開発を誘導する都市構造再編が一貫して第一に掲げられ、東京圈を貫く三環 状道路の整備に費用がかけられるなかで、東京都全域に配分される医療・福祉・教育関係 の支出は削減されていた。東京の空間再編は、市場領域や国家・自治体のネオリベラル的 再編によって可能になっており、領域間の連関をみることが重要である。国や都のネオリ ベラル的空間再編は23区の都市計画にも影響を与え、区によっては極端な開発規制の緩 和を行っていた。バブル崩壊後の日本、東京都、23区の施策・制度の変化は、ネオリベラ ル化があらゆる空間スケールと領域で進行していることを示す。

欧米諸都市のネオリベラル化が、国家・自治体の担ってきた階層間再分配システムの創 造的破壊をもたらしたとするならば、日本拉よび東京のネオリベラル化は開発主義国家の 地域間・産業間の再分配システムの創造的破壊であり、空間の再編に最も特徵が表れてい た。成長する都市への集中投資や政府主導の大型再開発は欧米都市にも共通する現象であ る。しかし、東京の場合、既存の都市開発体制と地域格差構造にのって市場志向の空間再 編を進めた点が特徴的であり、既存の空間構造をひっくり返すような大型再開発を進める 欧米都市とは異なる。欧米都市では、政府が主導する大型再開発やそれに付随するジェン トリフィケーションが、立ち退きを迫られる労働者階級やホームレスと警察の間に激しい 衝突を生み出し、「報復都市」 $[$ Smith，1996=2005］の様相を示している。ただし、東京と 欧米都市における都市空間をめぐる闘争の激しさの違いが、都市の社会空間構造や政府の 空間統制の強さ、市民社会の性向とどのように関連するかはさらなる検討が必要だろう。

東京都のネオリベラル化の推進力となったのは、財政危機と国際競争に抒ける地位低下 への不安であった。アジア諸都市が猛追する中で既に東京の国際的地位は下がっており、 「世界都市」の座を取り戻すために東京都のネオリベラル的な制度改革と空間再編が企て られた。だが、東京都の「世界都市」化戦略にも関わらず、2009年の株式売買高で東京 は上海証券取引所に追い抜かれた。東京が国際的な都市間競争のなかにとどまる間は、市 場からのネオリベラル化の圧力はなくならない。財政が許す限り、東京都のネオリベラル 的な「世界都市」化戦略は続くだろう。

本論文では、バブル崩壊後の東京の空間再編を推し進めた政治体制を検討し、開発主義 
国家型都市における「ネオリベラル化」の特徵を示してきた。ネオリベラル化」は変化の 方向を問う上で有効な概念であり、ネオリベラリズムとは正反対に思われる開発主義国家 に対しても、その体制のどの部分がどのくらい市場原理によって再編されるかを検討可能 にする。この概念を用いることで、異なる領域、空間スケール、地域におけるネオリベラ

付表1 日本および東京都におけるネオリベラル化(1980年代〜2007年)

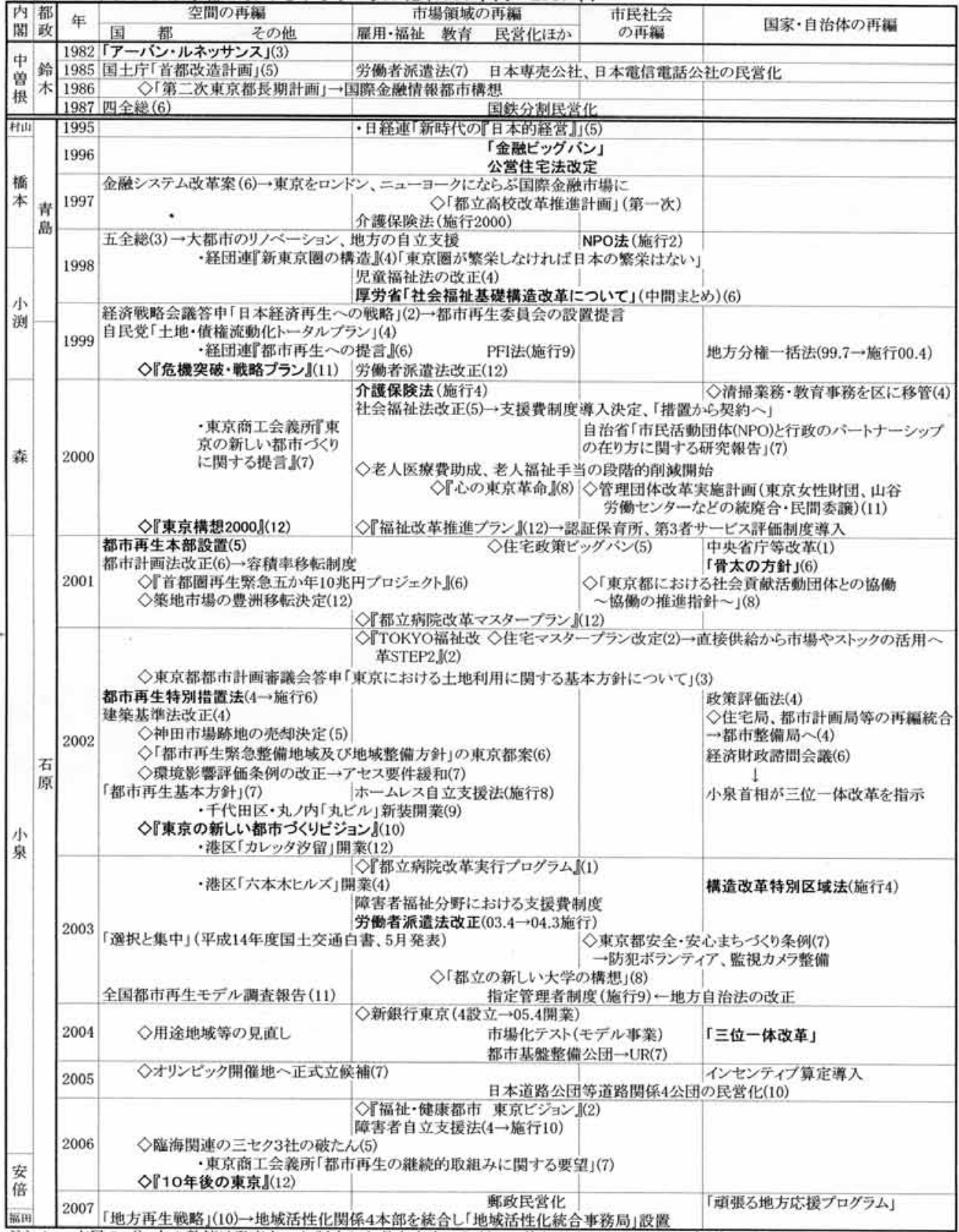

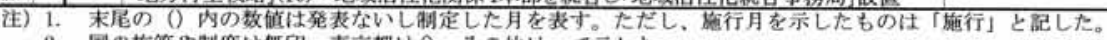

2. 国の施策や制度は無印、東京初はく、その他は・で示した。 
ル的再編が連関し、東京の空間再編が進んだことを指摘した。しかし、変化は各領域のな かで常に一方向へ起きているのではない。東京23区のなかの開発方針の差異は、ネオリ ベラル化が一様に進行しているのではないことを示しており、こうした差異が生じる要因 を今後は丁寧に見ていく必要がある。

注

1) 本論文で分析対象とする地理的範囲は東京都である。ただし、都市空間としての東京と行為者 （自治体）としての東京を区別するため、本文で都市空間としての東京に言及するときは「東京」、 自治体としての東京に言及するときは「東京都」と記して区別する。

2) Fujita and Hill [2008]のネオリベラリズムの理解はB. Jessop [2002]の議論に依拠するが、N. Brenner らに比べて、B. Jessop はネオリベラリズムをリベラリズムの発展形として狭く捉える傾 向にある。

3） 1970 年代以降、現金給与額とともに企業が支払う福利厚生費は大きく伸びた。ただし、健康保 険や厚生年金保険、雇用・労災保険などの「法定福利費」の比率が一貫して増加傾向であるのに 対し、企業が任意に行う福利厚生施策の費用である「法定外福利費」の比率はやや減少傾向にあ る [(社) 日本経済団体連合会, 2007］。

4）生活保護をふくめて、失業、住宅、家族に充てられる社会保障費は、1990年代以降ずっと、社 会保障給付費全体の 1 割を超えることはない。社会保障費の8 割は年金と医療関連で占められ、 高齢者対策が中心である。

5)「三位一体改革」が進められた $2004 \sim 2006$ 年度の 3 年間で、使途が限定された国庫補助負担 金の廃止・縮減は約 4 兆 7 千億円、地方が自由に使える地方交付税の削減は約 5 兆 1 千億円にのぼ る一方、国から地方への税源移譲は約 3 兆円にすぎず、税収の乏しい自治体にとっては大幅な収 入減を招いた。

6) 本節では、東京都の事業のうち重点事業の費用のみを分析したが、道路に特化する傾向は東 京都の普通建設事業費の変遷からも読み取れる。普通建設事業費の総額は 1998年から 2005年 まで一貫して減少し、都立病院関係や都営住宅関係などの建設投資が大幅に圧縮され、ほぼ停 止される一方、道路関係とりわけ街路整備などの大規模な投資が集中的に進められている [今井, 2007: 83]。

7）現行法は、地区計画策定の要件として関係地権者等の意見をきくことを求めており、合意形成 は求めていないが、実際の運用では大半の関係者の合意を得て決定されている。

8） 23 区の用途地域等の決定権限は東京都にあるが、見直しに際して、都は区市町に原案策定を依 頼して都の素案作成時には区市町の原案を尊重し、また用途地域等を変更する際には地区計画の 策定を要件とした。

\section{参考文献}

Brenner, N., and N. Theodore, 2002, "Cities and the Geographies of 'Actually Existing Neoliberalism," Antipode, 34(3): 349-79.

Fujita, K., 1991, "A World City and Flexible Specialization: Restructuring the Tokyo Metropolis," International Journal of Urban and Regional Research, 15: 269-85.

Fujita, K., 2003, “Neo-industrial Tokyo: Urban Development and Globalisation in Japan's State-centred 
Developmental Capitalism," Urban Studies, 40(2): 249-81.

Fujita, K., and R. C. Hill, 2008, "Tokyo's Urban Redevelopment Projects and the Post-Developmental State,” paper presented at the ISA First World Forum of Sociology, Barcelona, Spain, September $5-9$.

Friedmann, J., 1986, “The World City Hypothesis," Development and Change, 17: 69-83.

橋本健二, 2007,「「格差社会」における階級・階層研究と地域社会研究一「土地の社会移動研究」の 提案」『地域社会学会年報第19集 階層格差の地域展開』12-30.

Hill, R. C., and K. Fujita, 1995, “Osaka’s Tokyo problem,” International Journal of Urban and Regional Research, 19: 181-193.

Hill, R. C., and J. W. Kim, 2000, "Global Cities and Developmental States: New York, Tokyo and Seoul," Urban Studies, 37(12): 2167-95.

今井拓, 2007,「構造改革下の公共事業の変質と石原都政」小宮昌平・岩見良太郎・武居秀樹編『石 原都政の検証一世界都市・マネーゲーム・大東京主義』青木書店.

石田浩, 2008,「世代間移動の閉鎖性は上昇したか」『社会科学研究所パネル調査プロジェクト・ディ スカッションペーパー』17: 1-20.

Jessop, B., 2002, “Liberalism, Neoliberalism, and Urban Governance: A State Theoretical Perspective," Antipode, 34(3): 452-472.

加茂利男，2005，『世界都市一「都市再生」の時代の中で』有斐閣.

久保木匡介, 2004,「特別区におけるNPM行政改革の現段階」進藤兵・久保木匡介『地方自治構造 改革とニュー・パブリック・マネジメント』東京自治問題研究所: 77-126.

町村敬志，1994,『「世界都市」東京の構造転換一都市リストラクチュアリングの社会学』東京大学 出版会.

町村敬志，1998，「バブル期以降における都市階層変動一東京を事例に」倉沢進先生退官記念論集 刊行会編『都市の社会的世界』UHP出版.

丸山真央, 2010,「ネオリベラリズムの時代における東京の都市リストラクチュアリング研究に向け て」曰日本都市社会学会年報』28: 219-235.

（社）日本経済団体連合会. 2007。『第50回 福利厚生費調査結果（2005年度）」の概要』(http:// www.keidanren.or.jp/japanese/policy/2007/004.html、アクセス日2008/08/20)

大竹文雄, 2005, 『日本の不平等』日本経済評論社.

太田清, 2006,「「ジニ係数」分析一若年層の所得格差は 97 年以降に拡大していった」『週刊エコノミ スト』84(16): 28-29.

Peck, J., and A. Tickell, 2002, “Neoliberalizing Space,” Antipode, 34(3): 380-404.

Sassen, S., 1991, The Global City: New York, London, Tokyo, Princeton University Press.

盛山和夫, 2000,「中流崩壊は「物語」にすぎない」『中央公論』115(12): 84-91.

進藤兵，1998，「『都市福祉国家』から『世界都市』へ II 一東京都行政『改革』史序説・1975-1998 (1)」『名古屋大学法政論集』176: 1-66.

進藤兵，2009，「デー夕から見る石原都政の 10 年間一世界都市戦略、二極分化、そして新自由主義 改革」『世界』798: 140-148.

Smith, N., 1996, “Is Gentrification a Dirty Word?” in Smith, Neil, The New. Urban Frontier: Gentrification and the Revanchist City.（=2005, 若松司訳「ジェントリフィケーションは卑劣な言葉なのか」 『現代思想』33(5): 121-141.)

園部雅久，2001，『現代大都市社会論一分極化する都市？』東信堂. 
高木恒一, 2008,『再都市化段階における都市空間構造と政策対応に関する研究』(2006年度〜 2007 年度科学研究費補助金基盤研究 (C) 研究成果報告書).

武川正吾, 2007, 『連帯と承認一グローバル化と個人化のなかの福祉国家』東京大学出版会.

谷口聡, 2008, 「足立区教育改革の構造と問題一学力向上施策に着目して」佐貫浩・世取山洋介編

『新自由主義教育改革一その理論・実態と対抗軸』大月書店：64-82.

東京都, 2000, 『東京構想2000一千客万来の世界都市をめざして』東京都.

上村敏之・田中宏樹編著, 2006,『「小泉改革」とは何だったのか』日本評論社.

上野淳子, 2008,「規制緩和にともなう都市再開発の動向一東京都区部における社会一空間的分極 化」『日本都市社会学会年報』26: 101-115.

渡戸一郎, 2009,「インナーシティ自治体における『協働』政策の構築と課題一豊島区と新宿区のケ ーススタディ」『グローバル都市研究』2: 107-124.

渡辺治, 2004, 「開発主義・企業社会の構造とその再編成」渡辺治編『変貌する〈企業社会〉日本 一一橋大学大学院社会学研究科先端課題研究 1 』旬報社: 23-114.

矢作弘, 2002,「究極の『開発の自由』は何をもたらすのか』世界』706: 241-250.

謝辞 本稿は、平成 $19 \sim 21$ 年度科学研究費（特別研究員奨励費）による研究成果である。また、

丸山真央氏と仁平典宏氏との共同研究および一橋大学東京プロジェクト研究会（町村敬志、相川 陽一、植田剛史、神山育美、寺田篤生、松林秀樹、村瀬博志、山本唯人の各氏）の議論に負うと ころが大きい。記して感謝したい。

(うえのじゅんこ／桃山学院大学社会学部・講師） 